\title{
Brown rot caused by Monilinia fructicola on Japanese plums in Turkey
}

\author{
Ayşe Uysal-Morca ${ }^{1}$ (D) Pervin Kinay-Teksür ${ }^{2}$
}

Received: 28 August 2019 / Accepted: 3 December 2019/Published online: 19 December 2019

(C) Società Italiana di Patologia Vegetale (S.I.Pa.V.) 2019

Keywords Japanese plum $\cdot$ Brown rot $\cdot$ Monilinia fructicola $\cdot$ PCR

Monilinia fructicola (Winter) Honey is an important causal agent of brown rot of stone fruits, which is present in Asia, Oceania, North and South America but listed as a quarantine organism in Europe. In 2018, surveys were carried out in plum orchards of Izmir and Çanakkale provinces in Aegean region. Four isolates were collected from infected fruits of Japanese plums (Prunus salicina). Observed symptoms include necrotic lesions and rots on mature fruits. Pathogenicity was tested by inoculating healthy surface-sterilized Japanese plums fruit with agar plugs bearing mycelia from a 5-day-old culture. Control fruits were inoculated with sterile agar plugs. After 5 days of incubation at $22 \pm 2{ }^{\circ} \mathrm{C}$ and $95 \%$ relative humidity, typical brown rot symptoms developed around the inoculation point, while controls showed no symptoms. In the pathogenicity tests, the isolates caused lesions with sizes ranging from 4.0 to $6 \mathrm{~cm}$ on fruit while no lesions developed on control fruits. The pathogen was reisolated from lesion margins. The isolates were identified as M. fructicola based on morphological and molecular characters and sequence analysis. Colonies were yellowish gray and dense, with hazel sporogenous mycelium. Sporulation was abundant and usually developed in concentric rings. The lemon shaped spores had an average size of 7-12.5 $\times 15-17.5 \mu \mathrm{m}$, which is consistent with M. fructicola. Morphological characterization was confirmed by PCR with ITS specific primers ITS1Mfcl-F and ITS4MfclR (Ioos and Frey 2000). Sequences of the PCR products for all two isolates were deposited in GenBank with the accession numbers MH890478 and MH890479. BLASTn analyses of the PCR products revealed between $99.63-100 \%$ identity with reference sequence KX982695, from CBS 329.35 (Honey 1928 ) in NCBI GenBank. To our knowledge, this is the first report of presence of $M$. fructicola causing brown rot disease on Japanese plums in the Aegean region, Turkey. In the Japanese plum orchards where the pathogen was found, the necessary quarantine measures were quickly taken to prevent the spread of the disease.

\section{References}

Honey EE (1928) The monilioid species of Sclerotinia. Mycologia 20: 127-157

Ioos R, Frey P (2000) Genomic variation within Monilinia laxa, $M$. fructigena and $M$. fructicola, and application to species identification by PCR. Eur J Plant Pathol 106:373-378

Publisher's note Springer Nature remains neutral with regard to jurisdictional claims in published maps and institutional affiliations.

Ayșe Uysal-Morca

ayse.uysal@tarimorman.gov.tr; ayseuuysal@gmail.com

1 Directorate of Plant Central Protection Research Institute-Ankara, Ankara, Turkey

2 Department of Plant Protection, Faculty of Agriculture, Ege University, İzmir, Turkey 